\title{
STRUCTURAL DYNAMIC TESTING RESULTS FOR AIR-INDEPENDENT PROTON EXCHANGE MEMBRANE (PEM) FUEL CELL TECHNOLOGIES FOR SPACE APPLICATIONS
}

\author{
Ryan P. Gilligan', Ian J. Jakupca ${ }^{2}$, Phillip J. \\ Smith, William R. Bennett, Monica C. Guzik, and \\ Henry Kacher \\ NASA John H. Glenn Research Center \\ Cleveland, $\mathrm{OH}$
}

\section{ABSTRACT}

In 2016, the National Aeronautics and Space Administration (NASA) Advanced Exploration Systems (AES) project office funded testing at the NASA Glenn Research Center to evaluate the maturity of the Proton Exchange Membrane (PEM) fuel cell technology and its viability for supporting launch vehicle and space applications. This technology evaluation included vibration, reactant purity, and vacuum exposure sensitivity testing. The evaluation process did not include microgravity testing. This paper discusses the vibration sensitivity testing of two air-independent fuel cell stacks provided by different vendors to assess the ability of currently available fuel cell stack hardware to survive the projected random vibrational environment that would be encountered in an upper stage launch vehicle. Baseline performance testing was utilized to quantify stack performance and overboard leak rate at standard atmospheric conditions in order to provide a reference for posttest comparison. Both fuel cell stacks were tested at a random vibration qualification level of $10.4 \mathrm{~g}_{\mathrm{rms}}$ for five minutes in each axis. Low-level sinusoidal sweeps were conducted before and after each random vibration level run to see if any significant change in resonances were detected. Following vibration facility testing, the baseline performance testing was repeated. Test results demonstrated no measurable change in fuel cell electrochemical or mechanical performance, indicating that the two evaluated PEM fuel cell stacks may be suitable for space applications pending microgravity testing.

\section{ACRONYMS}

AES Advanced Exploration Systems

AMPS AES Modular Power Systems

CTB Common Test Bed

\footnotetext{
${ }^{1}$ Contact author: ryan.p.gilligan@nasa.gov

${ }^{2}$ Contact author: ian.j.jakupca@nasa.gov
}
$\mathrm{g}_{\mathrm{rms}}$
GRC
Root mean square of acceleration load
LVUS
NASA
Glenn Research Center
Launch Vehicle Upper Stage
PEM
Administration
SDL
Proton Exchange Membrane
TRL

\section{INTRODUCTION}

Fuel cells are energy conversion devices that convert chemical potential energy into electrical energy. Proton Exchange Membrane (PEM) fuel cells consume hydrogen and oxygen gas to produce electricity, heat, and water. Trade studies have indicated that PEM fuel cells provide a significant mass benefit over battery systems traditionally used on the upper stages of launch vehicles for mission durations longer than several hours [1]. This trade is currently restricted to launch vehicle upper stages (LVUSs) utilizing cryogenic hydrogen and oxygen propellants because the propellant boil off which would otherwise be wasted can be used as reactants for the fuel cell to power the LVUS [2]. In addition to providing electrical power to the upper stage vehicle, the waste heat produced can also help maintain electronics within operational or survival temperature ranges.

Prior to incorporation into an upper stage design, further work was needed to adapt the technology to meet typical launch vehicle requirements. In 2016 the Advanced Exploration Systems (AES) program office and NASA Glenn Research Center (GRC) entered a partnership with an upper stage developer to assess the PEM fuel cell technology. Together, the AES Modular Power Systems (AMPS) project and the upper 
stage developer created requirements and then tested subscale hardware with extensibility to a launch vehicle upper stage application. Subscale stack hardware testing focused on testing existing state of the art fuel cell stacks in order to inform a final design capable of meeting LVUS requirements. The testing approach reduced the risk associated with qualifying fuel cell stack hardware for Technology Readiness Level (TRL) 6 in anticipation of a near-term flight application. This paper focuses on one of the key areas identified for risk reduction testing: a vibration test of existing subscale fuel cell stacks at the expected levels encountered during a LVUS flight.

A test series was conducted to assess the ability of currently available air-independent fuel cell stack hardware to survive the projected random vibrational environment that would be encountered in a LVUS application. Air-independent fuel cell stacks do not rely on ambient air for an oxidizer but instead utilize a dedicated oxygen supply. Air independent stacks also have the ability to passively remove product water from the stack without using power or rotating components [3]. Two vendors provided NASA with one air-independent fuel cell stack each to test. Infinity Fuel Cell and Hydrogen supplied a stack without a vibration-isolation mount and Teledyne Energy Systems delivered a single air-independent stack that included a vibration dampening mount.

\section{TEST PLAN}

The test was segmented into 3 stages: baseline performance testing of the fuel cell stacks, vibration facility testing, and postvibration comparative performance testing. Baseline performance testing quantified stack electrochemical performance when subjected to a standardized load profile and a helium overboard leak rate at standard atmospheric conditions in order to provide a reference for post-test comparison. Vibration facility testing consisted of random vibration of the fuel cell stacks while pressurized with gaseous helium at the vendorspecified operating pressure. Following vibration facility testing, the baseline performance testing was repeated for a postvibration performance comparison.

Two metrics were used to measure success: stack pressure decay rate and stack electrochemical performance. Stack pressure decay rate is defined as the quantity of observed pressure loss in the fuel cell stack (psid) over a ten minute period. During stack pressure decay rate testing the initial helium pressure was equal to the standard operating pressure defined for the stack. Stack performance is defined as the power response to the NASA 2 Hour Load Profile test, as measured by mapping the average cell voltage (V) against the current density $\left(\mathrm{mA} / \mathrm{cm}^{2}\right)$.

Success for both metrics was determined by comparing the post-vibration comparative performance testing data to the baseline performance testing data. The success criteria tolerance was $\pm 10 \%$ variance between baseline and post vibration test data for both the stack performance and pressure decay rate metrics. Fuel cell stack performance is dependent on stack temperature and reactant pressures. An uncertainty analysis was performed to evaluate these relations. The acceptance range incorporates experimental error due to pressure and temperature control precision limits within the test apparatus.

In addition to the pressure decay and electrochemical performance metrics, visual inspections of hardware were conducted to check for major structural anomalies during vibration testing. Sinusoidal sweeps at $0.25 \mathrm{~g}_{\text {rms }}$ peak amplitude were also conducted before and after each vibration test to determine if non-visible structural anomalies occurred via major shifts in resonant frequencies. A 5\% variability in resonance frequency shift was deemed acceptable by the project due to uncertainty associated with the test instrumentation and variability in the experimental setup. However, this metric for resonance response was not a concrete pass or fail evaluation.

\subsection{Baseline Performance Testing}

Baseline performance testing was conducted at the fuel cell test laboratory at NASA GRC. Testing consisted of measuring each fuel cell stack performance during the NASA 2 Hour Load Profile test and measuring stack pressure decay rate prior to vibration facility testing. The NASA 2 Hour Load Profile is an electrical load profile applied to a fuel cell stack that was developed during the Reusable Launch Vehicle program based on a Space Shuttle Orbiter mission. The load is scaled with the active area of the fuel cell stack so that the performance of fuel cells with differing active areas can be directly compared. Figure 1 shows the NASA 2 Hour Load Profile. A polarization curve is used to characterize fuel cell stack performance before and after the 2 Hour Load Profile. The Load Profile test reports the measured average cell voltage response to the stack current density demanded by the electrical load profile.

Fuel cell orientation and inlet pressure sensitivity testing were also performed as part of the LVUS application testing. For the purposes of generating baseline data prior to vibration testing, however, the fuel cell stack was tested in the standard orientation, with reactant delivery at the standard operating pressure for the stack as defined by each fuel cell vendor. Each NASA 2 Hour Load Profile test was performed at least three times for repeatability. The average response of the fuel cell stack is reported. This result is referred to as the Baseline Stack Performance.

Stack pressure decay rate is reported as the observed drop in pressure from its initial conditions at standard operating pressure over a ten minute period when the fuel cell stack is pressurized with gaseous helium. The ambient environment was at standard atmospheric conditions. This pressure decay rate test was performed three times for repeatability, and the average pressure decay rate is reported, with appropriate margins of error. This result is referred to as the Baseline Stack Pressure Decay Rate. 


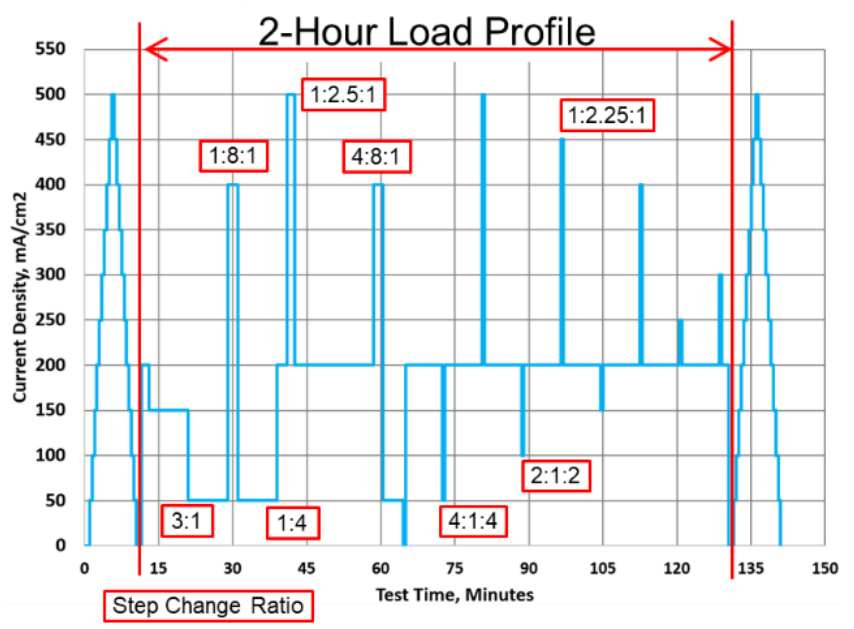

Figure 1. NASA 2 HOUR LOAD PROFILE.

\subsection{Vibration Facility Testing}

After the completion of baseline performance testing, the fuel cell stacks were relocated to the NASA GRC Structural Dynamics Laboratory (SDL) and readied for random vibration testing. A vibration mounting fixture was designed for the fuel cell stack provided by Infinity. The fuel cell was hard mounted to one end of the fixture and secured by a slide pin on the opposite side of the fixture. The fuel cell stack was oriented horizontally with both anode and cathode endplates oriented perpendicular to the vibration table surface. The fuel cell stack from Infinity was tested in 3 axes utilizing a 24 in. by 24 in. MB Dynamics C-60 shaker table. Figure 2 illustrates the orientation of each axis of the fuel cell relative to the vibration direction. Vibration testing occurred while the fuel cells were in a nonoperative (inert) state and pressurized with gaseous helium at standard operating pressure.
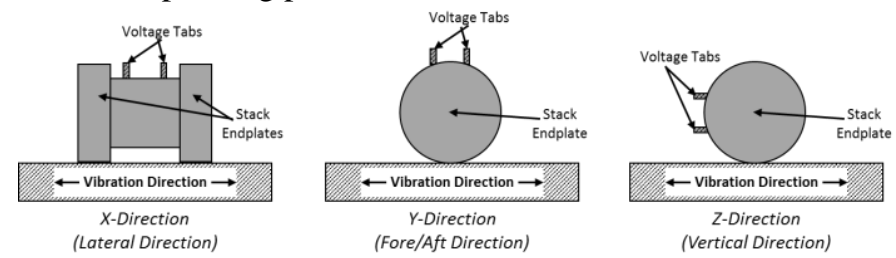

Figure 2. ORIENTATION OF INFINITY FUEL CELL STACK DURING VIBRATION TESTING.

Two control accelerometers were mounted on opposite sides of the mounting fixture for all vibration testing. One triaxial and one single axis response accelerometer were located on the endplates of the fuel cell. The triaxial response was located on the endplate closer to the hard mounted side of the fuel cell while the single axis response was located on the endplate on the pinned end. Both were used to collect vibration level data of the fuel cell. The single axis accelerometer was rotated into the direction of motion for each axis. A triaxial accelerometer was located at the center of the 3 mounting screws on the mounting bracket and a reference accelerometer was located at the base of a hard mount L-bracket that secured the fixture to the shaker table. The vibration inputs were controlled by the average of the two control accelerometer signals. Figure 3 shows the stack mounted on the test fixture and the location of some of these accelerometers denoted M3X, M7X, M8Y, M9Z, and M10X.

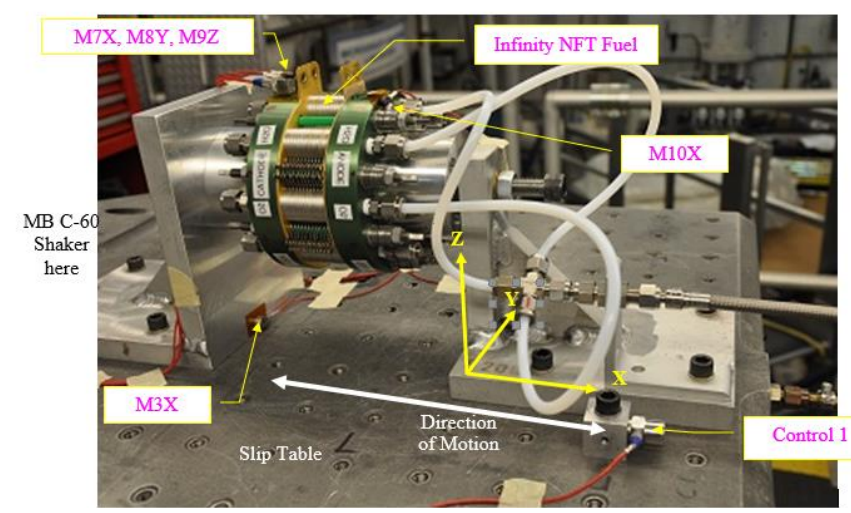

Figure 3. INFINITY FUEL CELL STACK MOUNTED ON SHAKER TABLE FOR TESTING IN X-AXIS.

Teledyne delivered a fuel cell to NASA with an integrated mounting fixture. The vendor test fixture was bolted to a $12 \mathrm{in}$. by 7 in. fixture plate. Figure 4 illustrates the orientation of each axis of the Teledyne fuel cell relative to the vibration direction. The fixture plate was mounted to a 24 in. by $24 \mathrm{in}$. MB Dynamics $\mathrm{C}-60$ shaker table for vibration testing in the $\mathrm{X}$ - and $\mathrm{Y}$-axes. For testing in the $\mathrm{Z}$ direction the fixture plate was mounted to a Ling Electronics 4022 shaker table with a 24 in. diameter mounting plate.

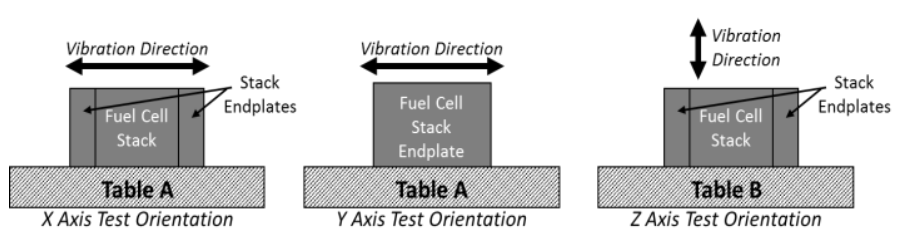

Figure 4. ORIENTATION OF TELEDYNE FUEL CELL STACK ON BOTH VIBRATION TABLES.

Two control accelerometers were mounted on opposite sides of the $12 \mathrm{in}$. by $7 \mathrm{in}$. fixture plate for all vibration testing. One triaxial and one single axis response accelerometer were located on the top corners of the fuel cell endplates. The triaxial response was located on a side of the fuel cell stack that had Belleville washers while the single axis response was located on the opposite side from the Belleville washers. Both were used to collect vibration level data of the fuel cell. The single axis accelerometer was rotated into the direction of motion for each axis. In addition a single axis reference accelerometer was located at the base of the hard mount L-bracket and was also rotated into the direction of motion for each axis. The vibration inputs were controlled by the average of the two control accelerometer signals. 
Sinusoidal and qualification level random vibration tests were conducted per program requirements on stacks from both vendors in all 3 axes. Prior to a vibration test the stacks were pressurized with gaseous helium to their standard operating pressure and a pressure decay rate was measured. If the stack pressure decay rate did not match baseline measurements, a leak check of the helium supply system fittings was performed and the measurement was repeated. After an initial pressure decay measurement a sinusoidal sweep of each fuel cell was performed to determine the resonant frequencies of the hardware. The sinusoidal level used was $0.25 \mathrm{~g}_{\mathrm{rms}}$ peak from 5 to $2000 \mathrm{~Hz}$ at a sweep rate of 2 octaves/minute. After the sinusoidal sweep the fuel cells were tested at an applicable LVUS acceptance level twice in a single axis. A third run at representative LVUS qualification levels was then performed. The qualification random vibration level used was $10 \mathrm{~g}_{\mathrm{rms}}$ for five minutes duration in each axis. The helium pressure in the fuel cell was recorded during sine sweeps, acceptance level, and qualification level testing. A post qualification level sinusoidal sweep was performed to check for significant changes in resonant frequencies. A final pressure decay test was then conducted prior to removing each fuel cell from the shaker table and preparing for the next test.

\subsection{Post Vibration Comparative Performance Testing}

The electrochemical performance testing using the NASA 2 Hour Load Profile and pressure decay testing described in Section 2.1 were repeated after testing at the SDL. The previbration and post-vibration data were then compared to determine if the success criteria for the test series was met.

\section{RESULTS AND DISCUSSION}

\subsection{Infinity Fuel Cell Stack Vibration Testing Results}

The $\mathrm{X}$-axis vibration test results for the stack provided by Infinity are displayed in Figure 5 through Figure 7 based on the respective orientations illustrated in Figure 3. The control accelerometers ensured an excitation at the base of the test fixture to be at the required test levels. It was found during testing that the vibration fixture had resonances within the test's frequency range and amplified the excitation at these frequencies. This caused the actual hardware to see levels of $15.2 \mathrm{~g}_{\mathrm{rms}}$ at the fuel cell end plate with pin support and $16.9 \mathrm{~g}_{\mathrm{rms}}$ at the endplate fixed to the support as evidenced by the response accelerometers M10X and M7X, respectively. Testing in the $\mathrm{x}$ axis showed a $22.3 \mathrm{~Hz}$ variation in peak resonant frequency between pre- and post-qualification testing. This equates to a $4.1 \%$ variance, which is within the $5 \%$ uncertainty limit of the test apparatus and experimental setup. No visible structural anomalies were observed during $\mathrm{X}$-axis testing.

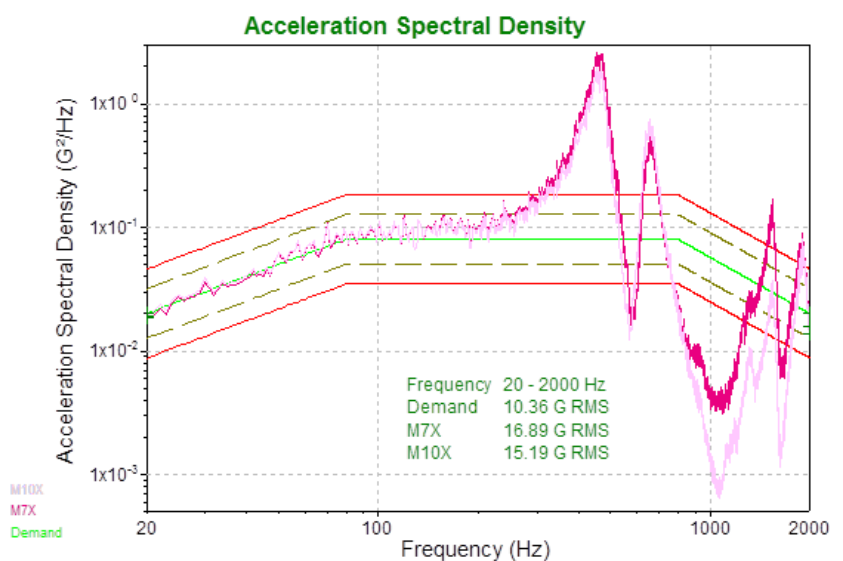

Figure 5. INFINITY X-AXIS QUALIFICATION LEVEL VIBRATION TEST RESULTS.

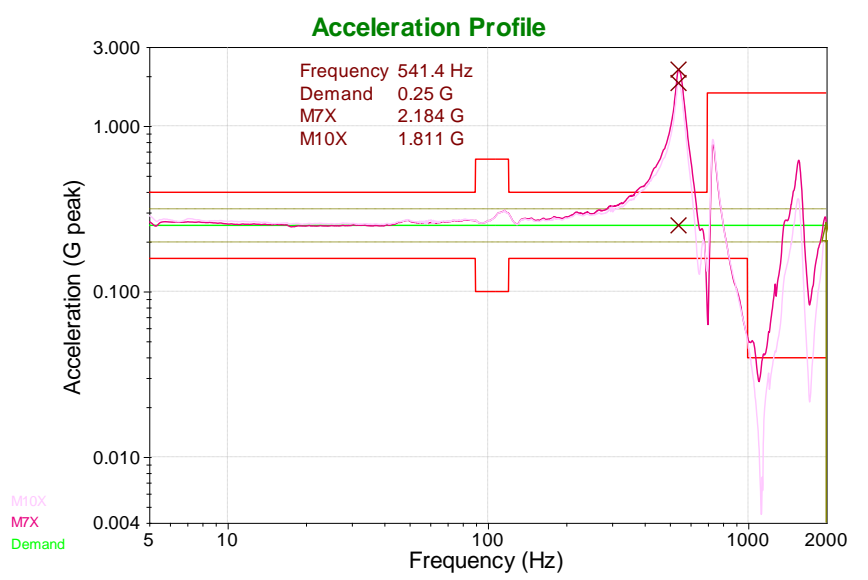

Figure 6. INFINITY PRE-QUALIFICATION TEST X AXIS SINE SWEEP.

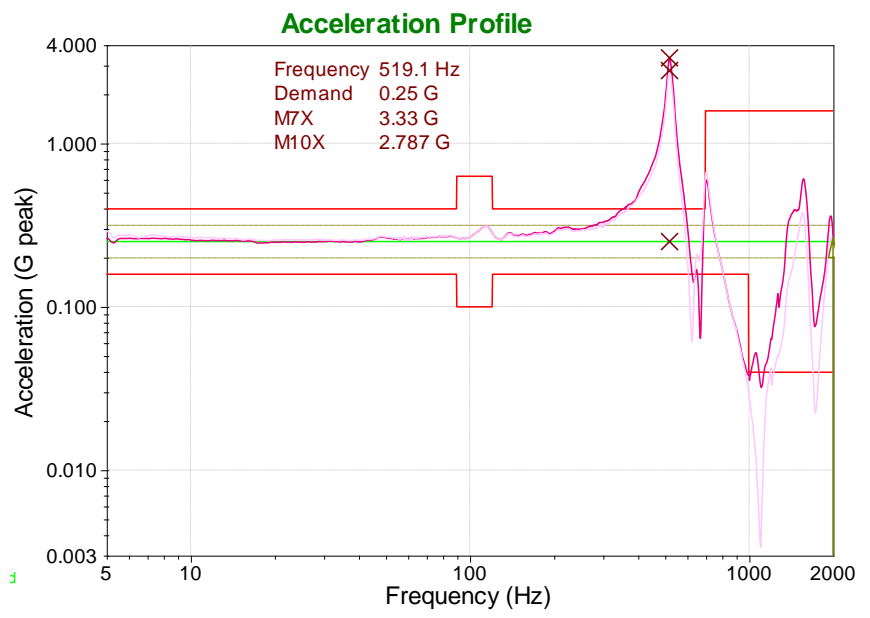

Figure 7. INFINITY POST-QUALIFICATION TEST X AXIS SINE SWEEP. 


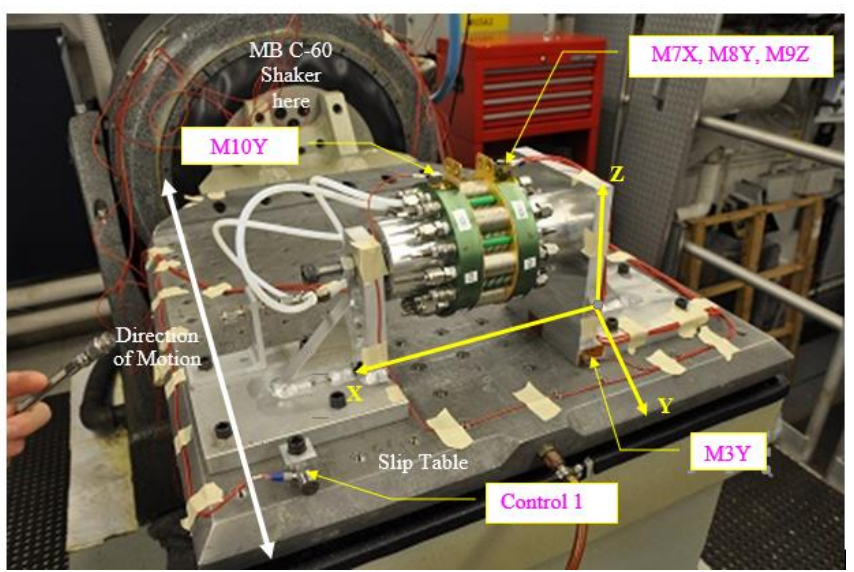

Figure 8. INFINITY FUEL CELL STACK MOUNTED ON SHAKER TABLE FOR TESTING IN Y-AXIS.

Figure 8 shows the Infinity stack orientation on the shaker table for testing in the Y-axis. The Y-axis vibration test results are displayed in Figure 9 through Figure 11. The vibration fixture had resonances within the test's frequency range and amplified the excitation at these frequencies. This caused the actual hardware to see levels of $41.2 \mathrm{~g}_{\mathrm{rms}}$ at the fuel cell end plate with pin support and $25.0 \mathrm{~g}_{\mathrm{rms}}$ at the endplate fixed to the support as evidenced by the response accelerometers M10Y and M8Y, respectively. Testing in the $\mathrm{Y}$-axis showed a $6.6 \mathrm{~Hz}$ variation in peak resonant frequency between pre- and post-qualification testing. This equates to a $1.8 \%$ variance, which is within the $5 \%$ uncertainty limit determined by the project. At the conclusion of Test Day 1, the fuel cell stack was to be rotated on its mount pin to be re-oriented for Z-axis testing. During this maneuver, it was discovered that the mount pin had been scored as shown in Figure 12 such that it would no longer move freely within the fixture mounting collar. The mount pin was freed and machined to smooth its surfaces. The mounting fixture was then reassembled on Test Day 2 to begin Z-axis testing.

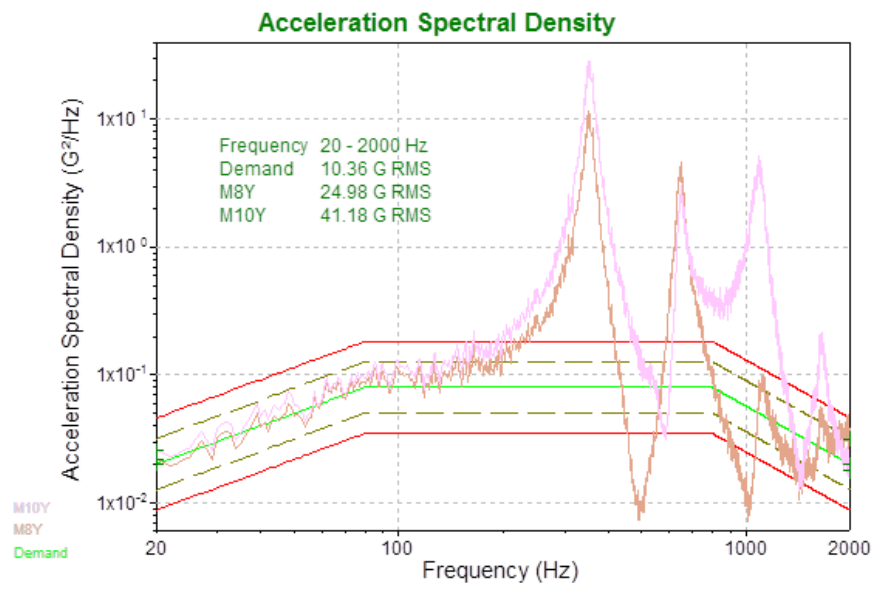

Figure 9. INFINITY STACK Y-AXIS QUALIFICATION LEVEL VIBRATION TEST RESULTS.

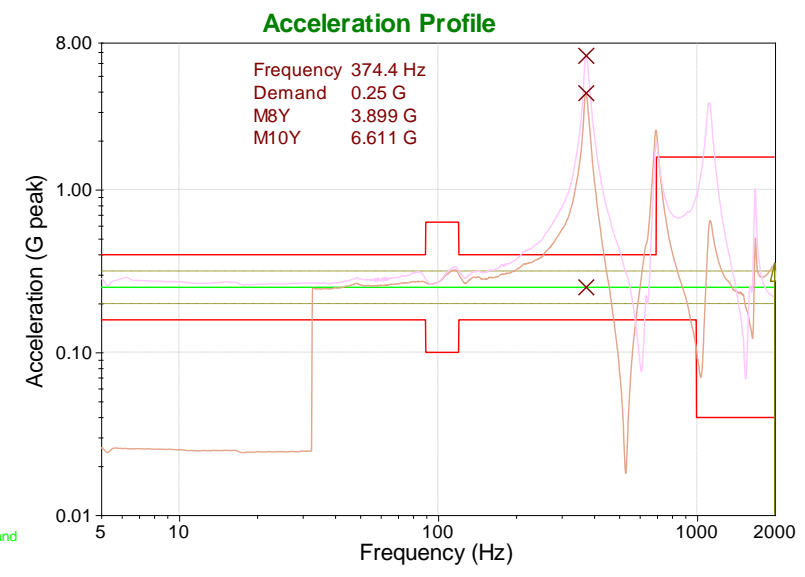

Figure 10. INFINITY FUEL CELL STACK PREQUALIFICATION TEST Y-AXIS SINE SWEEP.

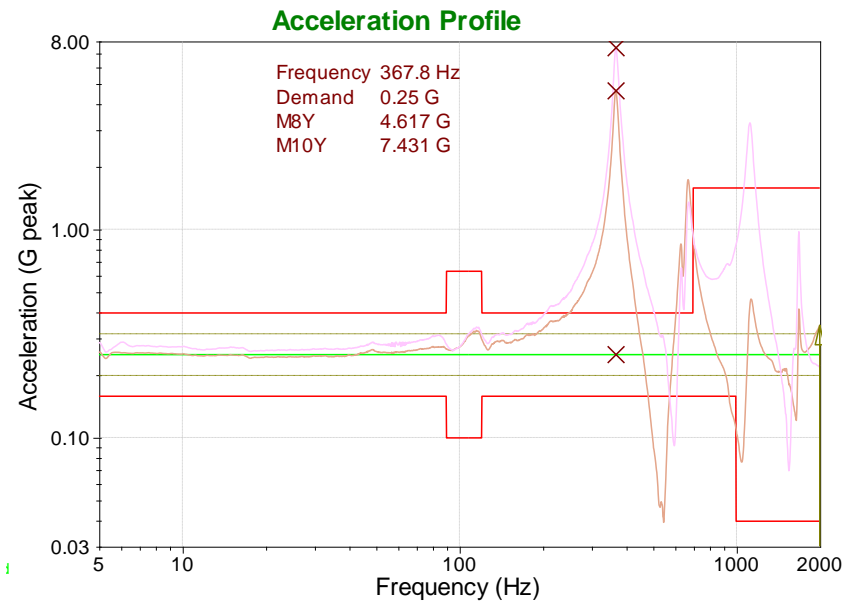

Figure 11. INFINITY FUEL CELL STACK POSTQUALIFICATION TEST Y-AXIS SINE SWEEP.

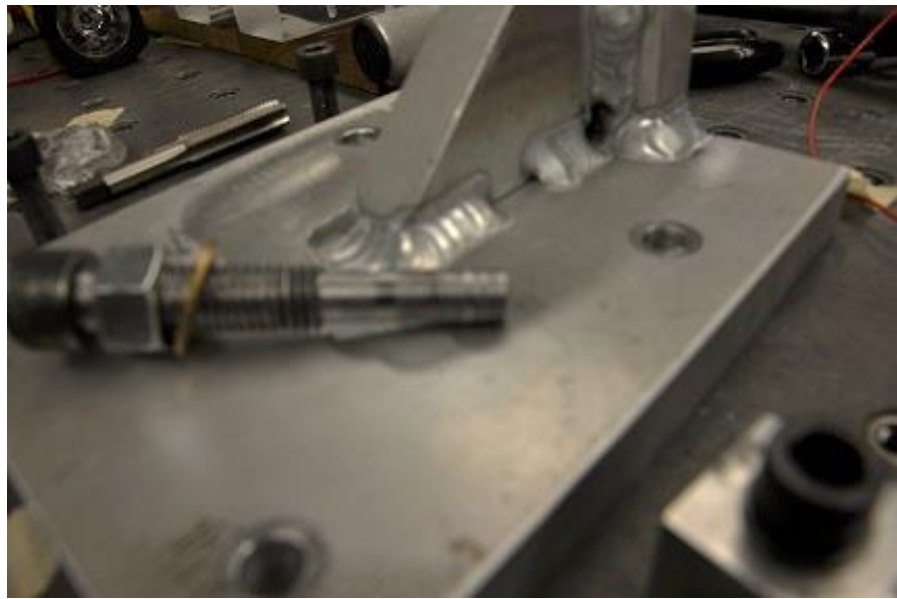

Figure 12. SCORED MOUNTING PIN DISCOVERED WHEN PREPARING FOR INFINITY STACK Z-AXIS VIBRATION TESTING. 
The Z-axis vibration test results are displayed in Figure 13 through Figure 15. The control accelerometers ensured an excitation at the base of the test fixture to be at the required test levels. The vibration fixture had resonances within the test's frequency range, which caused the actual hardware to see levels of $25.1 \mathrm{~g}_{\mathrm{rms}}$ at the fuel cell end plate with pin support as evidenced by the response accelerometer M10Z. The accelerometer on the fixed end of the support was not functioning during this test. Testing in the $\mathrm{Z}$-axis showed a 6.3 $\mathrm{Hz}$ variation in peak resonant frequency between pre- and postqualification testing. This equates to a $1.5 \%$ variance, which is within the $5 \%$ uncertainty limit. No visible structural anomalies were observed during $\mathrm{Z}$-axis testing.

During the Z-axis testing, it was noted that the resonant peak frequency was approximately $46 \mathrm{~Hz}(\sim 12 \%)$ different than that encountered in $\mathrm{Y}$-axis testing. To eliminate the mount pin issue as a cause for a significant resonant frequency shift, Y-axis testing was repeated at a lower random vibration level to avoid unnecessarily stressing the stack. The low level sinusoidal sweeps were also repeated before and after the lower random vibration level test. The $\mathrm{Y}$-axis resonant peak frequency prior to each $\mathrm{Y}$-axis vibration was shown to be within $1.5 \%$, suggesting the change in frequency between the Z-axes in Figure 14 and Figure 15 and Y-axes in Figure 10 and Figure 11 is due to geometry differences rather than the mount pin.

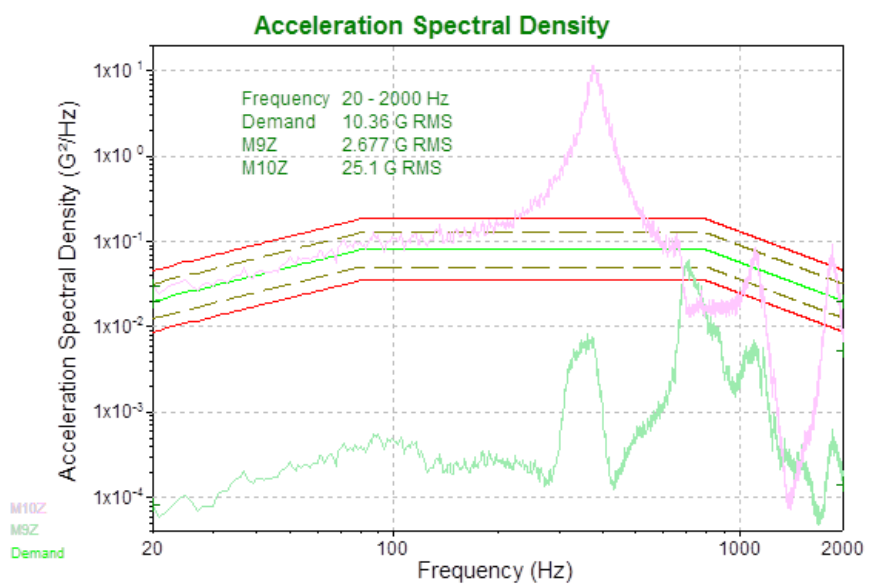

Figure 13. INFINITY STACK Z-AXIS QUALIFICATION LEVEL VIBRATION TEST RESULTS.

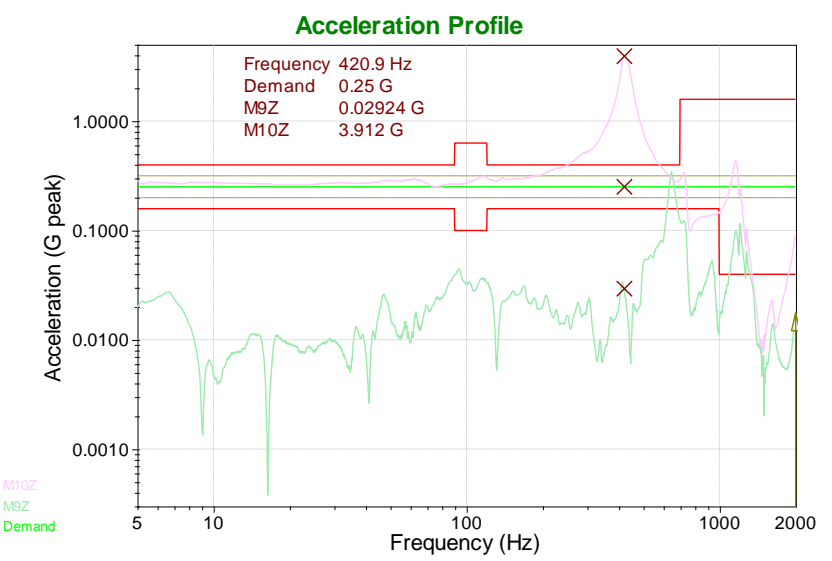

Figure 14. INFINITY STACK PRE-QUALIFICATION TEST Y-AXIS SINE SWEEP.

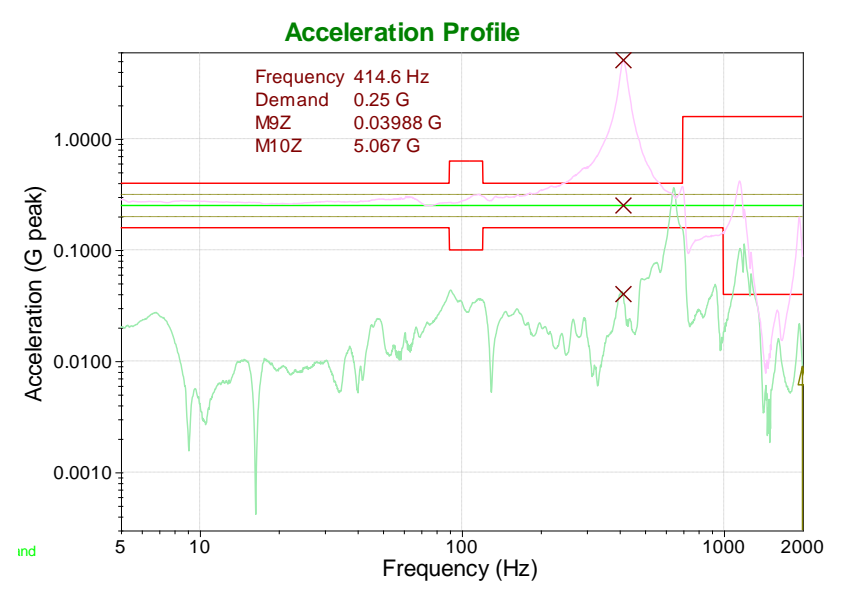

Figure 15. INFINITY STACK POST-QUALIFICATION TEST Y-AXIS SINE SWEEP.

\subsection{Teledyne Vibration Testing Results}

The Teledyne $\mathrm{X}$-axis vibration test results are displayed in Figure 16 through Figure 18. Figure 19 shows the orientation of the fuel cell stack on the shaker table for the $\mathrm{X}$-axis test. The control accelerometers ensured an excitation at the base of the test fixture to be at the required $10.4 \mathrm{~g}_{\mathrm{rms}}$. During testing the vibration fixture had resonances within the test's frequency range and amplified the excitation at these frequencies. The fuel cell endplate on the Belleville washer side experienced a 19.5 $\mathrm{g}_{\mathrm{rms}}$ load and the endplate with the fluidic interfaces experienced a $17.2 \mathrm{~g}_{\mathrm{rms}}$ peak load as indicated by the M5X and M7X tagged accelerometers, respectively. Testing in the $\mathrm{X}$-axis showed a 10 $\mathrm{Hz}$ variation in the first mode resonant frequency between preand post-qualification testing. This equates to a $4.1 \%$ variance, which is within the $5 \%$ uncertainty limit determined by the project. 


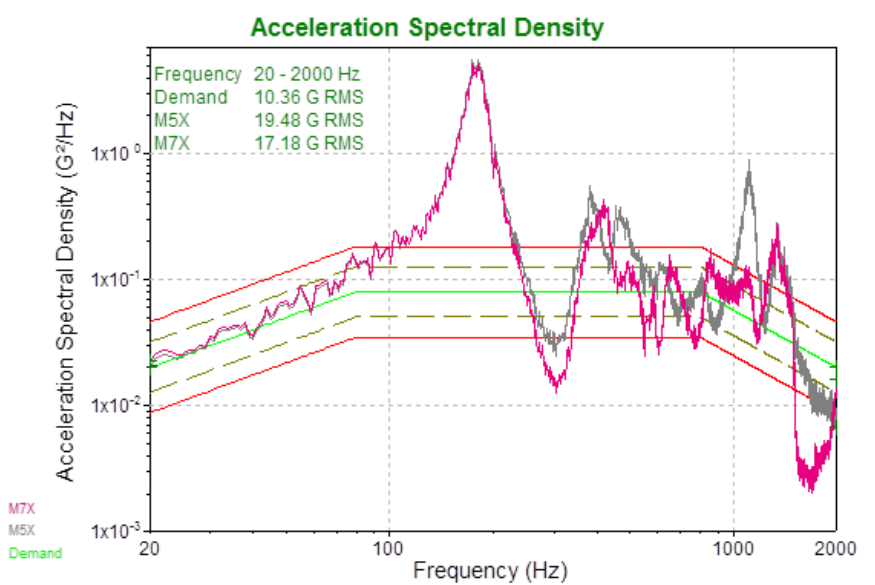

Figure 16. TELEDYNE X-AXIS QUALIFICATION LEVEL VIBRATION TEST RESULTS.

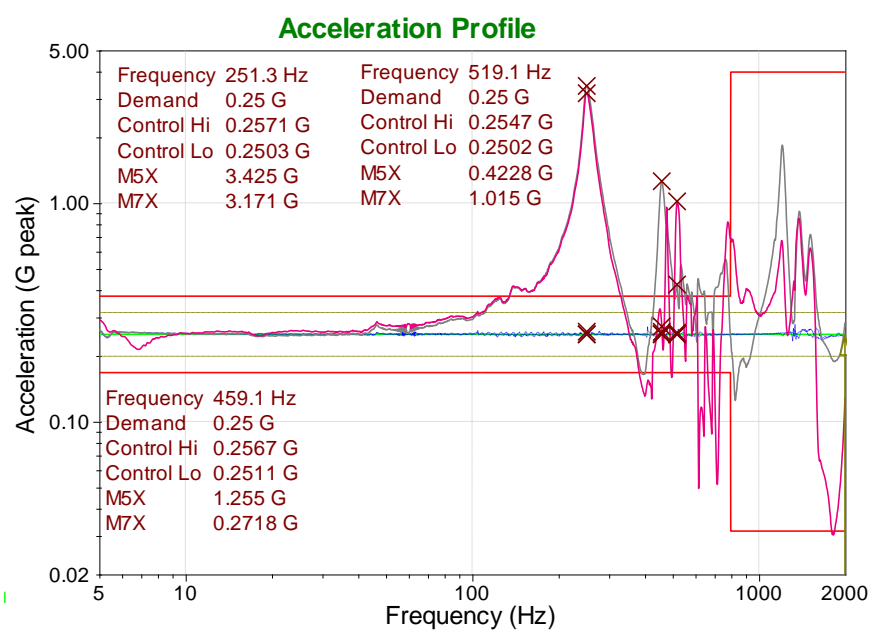

Figure 17. TELEDYNE PRE-QUALIFICATION TEST $X$ AXIS SINE SWEEP.

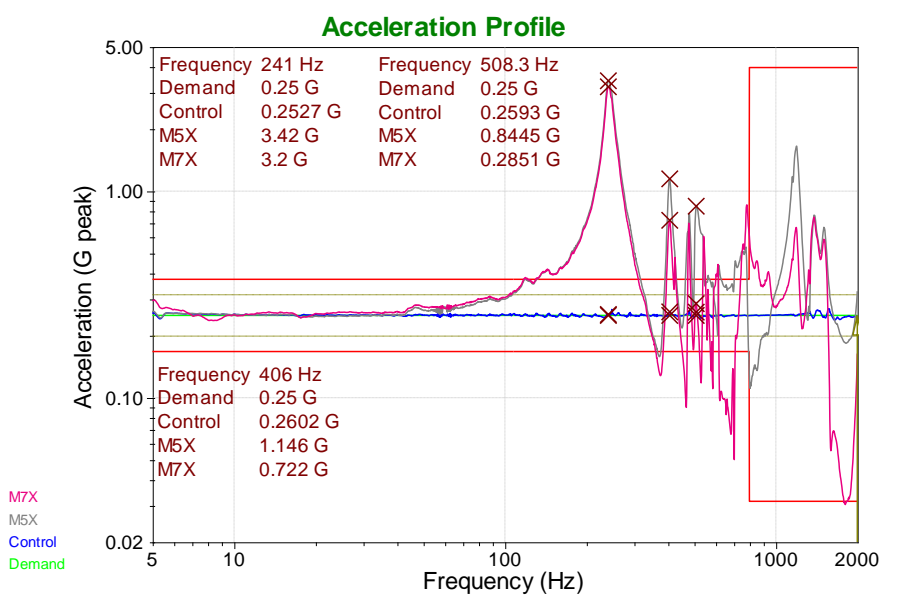

Figure 18. TELEDYNE POST QUALIFICATION TEST XAXIS SINE SWEEP.

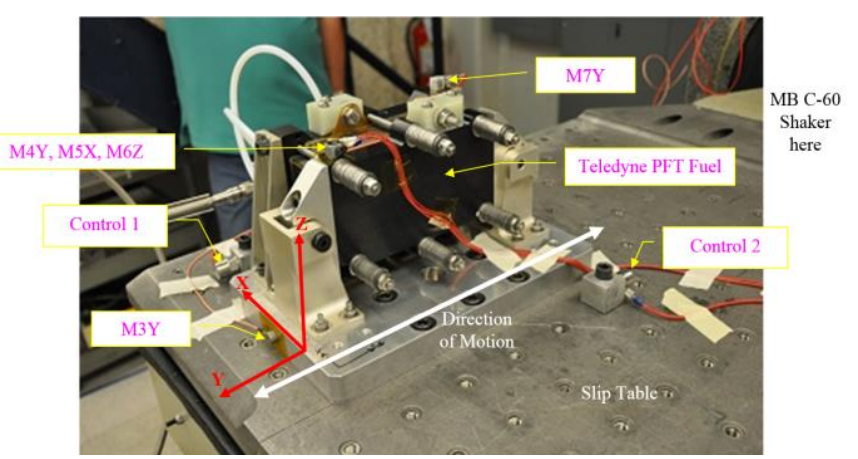

Figure 19. TELEDYNE FUEL CELL STACK MOUNTED ON MB C-60 SHAKER TABLE FOR TESTING IN Y-AXIS.

Figure 19 shows the Teledyne stack orientation on the shaker table for testing in the $\mathrm{Y}$-axis. The $\mathrm{Y}$-axis vibration test results are displayed in Figure 20 through Figure 22. The vibration fixture had resonances within the test's frequency range and amplified the excitation at these frequencies. The fuel cell endplate on the Belleville washer side experienced a 21.5 $\mathrm{g}_{\mathrm{rms}}$ load and the endplate with the fluidic interfaces experienced an $18.5 \mathrm{~g}_{\mathrm{rms}}$ peak load as indicated by the M5X and M7X tagged accelerometers, respectively. Testing in the Y-axis showed a 33 $\mathrm{Hz}$ variation in the first mode resonant frequency between preand post-qualification testing. This equates to a $7.5 \%$ variance, which is outside the $5 \%$ uncertainty limit. However, this response is similar to previously tested hardware at the SDL that used Belleville washers as the primary sealing method and was determined not to be a concern. No visible structural anomalies were observed during $\mathrm{Y}$-axis testing.

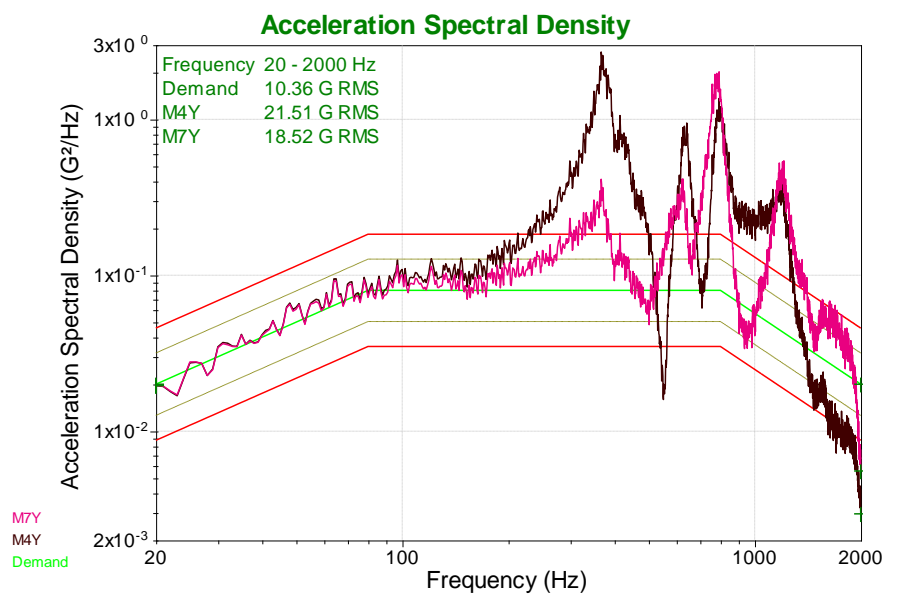

Figure 20. TELEDYNE Y-AXIS QUALIFICATION LEVEL VIBRATION TEST RESULTS. 


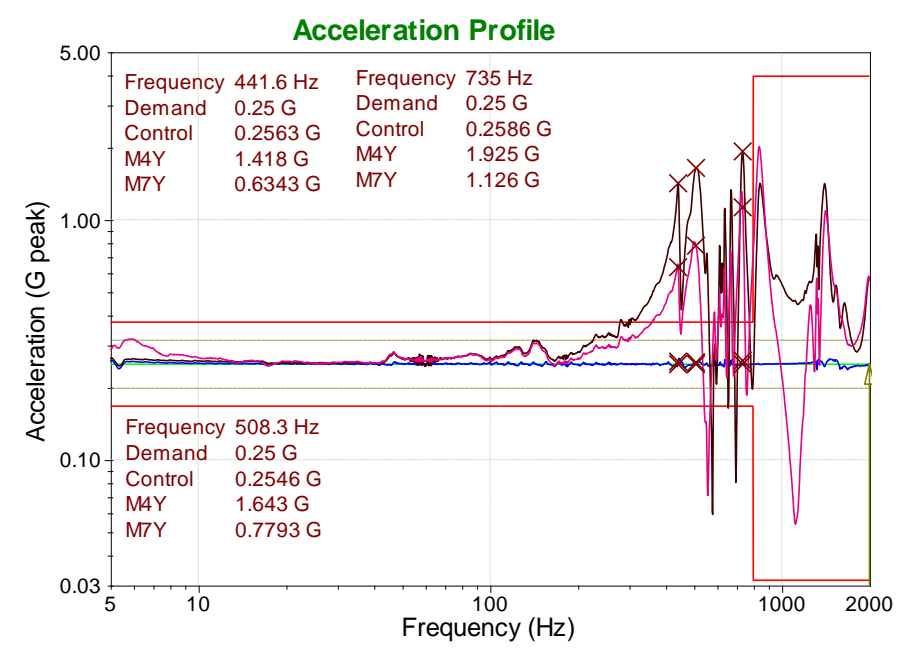

Figure 21. TELEDYNE PRE-QUALIFICATION TEST YAXIS SINE SWEEP.

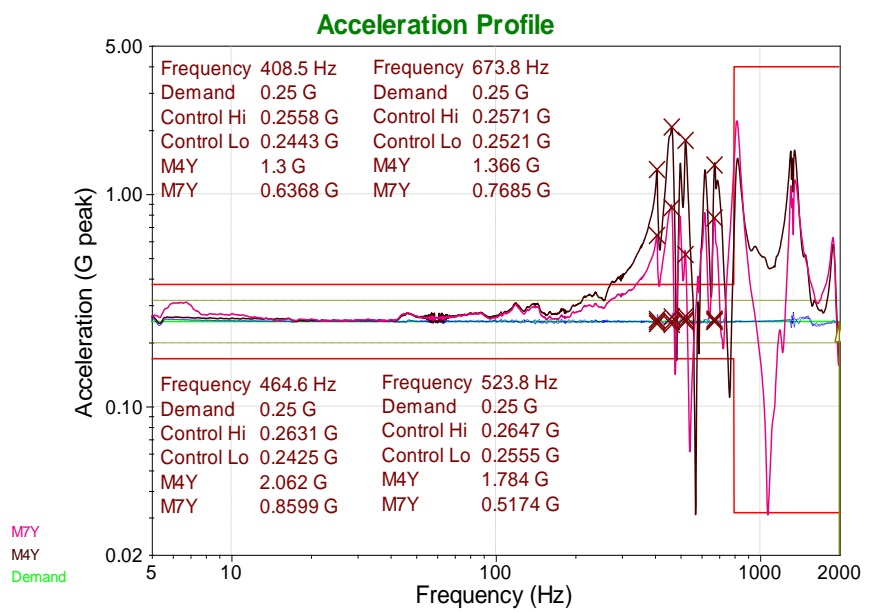

Figure 22. TELEDYNE POST-QUALIFICATION TEST YAXIS SINE SWEEP.

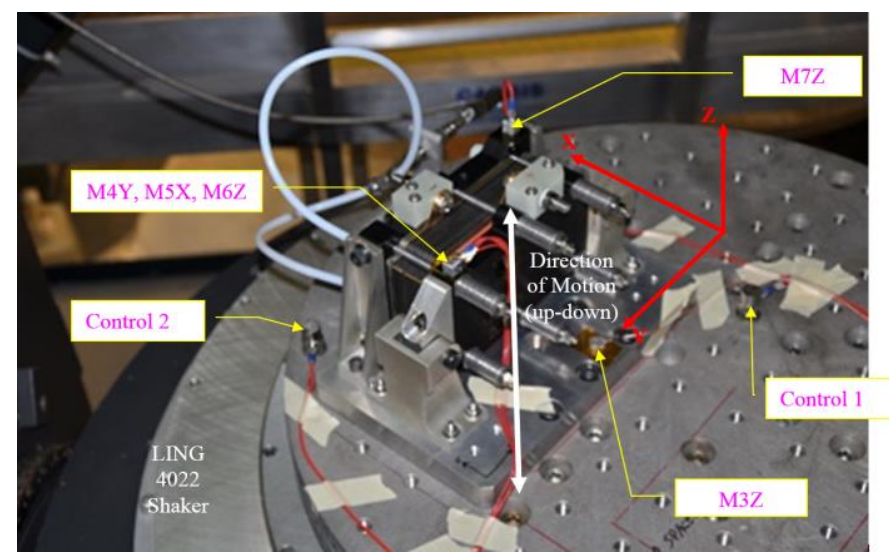

Figure 23. TELEDYNE FUEL CELL STACK MOUNTED ON LING 4022 SHAKER TABLE FOR TESTING IN Z-AXIS.
Figure 23 shows the Teledyne fuel cell stack mounted on the vertical shaker table for testing in the Z $\mathrm{Z}$-axis. The Z-axis vibration test results are displayed in Figure 24 through Figure 26. The vibration fixture had resonances within the test's frequency range and amplified the excitation at these frequencies. The fuel cell endplate on the side with the Belleville washers experienced a $15.3 \mathrm{~g}_{\mathrm{rms}}$ load as indicated by the M7Z tagged accelerometer. Testing in the Z-axis showed a $7 \mathrm{~Hz}$ variation in the first mode peak resonant frequency between preand post-qualification testing. This equates to a $2.6 \%$ variance, which is within the $5 \%$ uncertainty limit.

In future vibration testing, vibration fixtures should be designed to not have resonances within the test frequency. Alternatively, the control accelerometers could be located closer to the hardware-fixture interface to avoid hardware vibrational levels exceeding control levels.

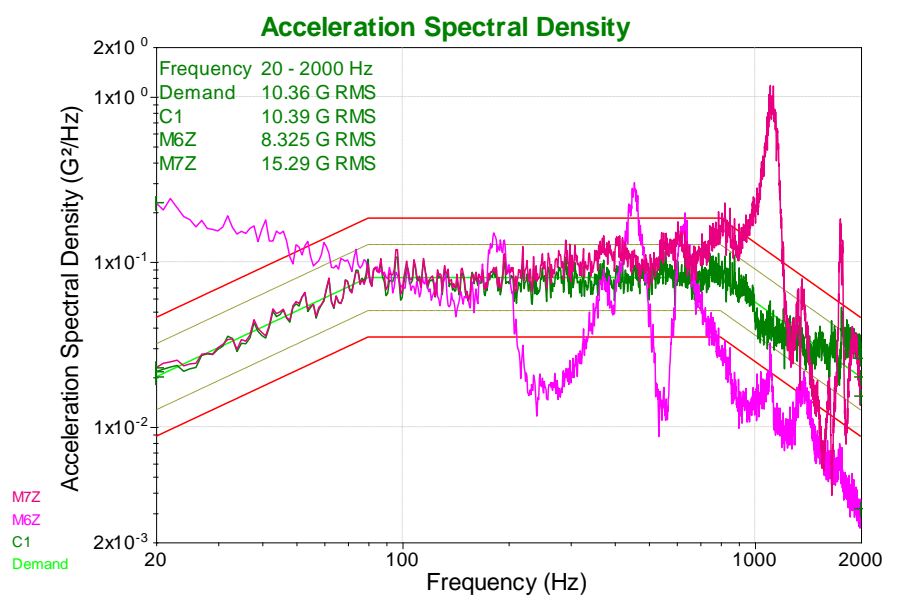

Figure 24. TELEDYNE Z-AXIS QUALIFICATION LEVEL VIBRATION TEST RESULTS.

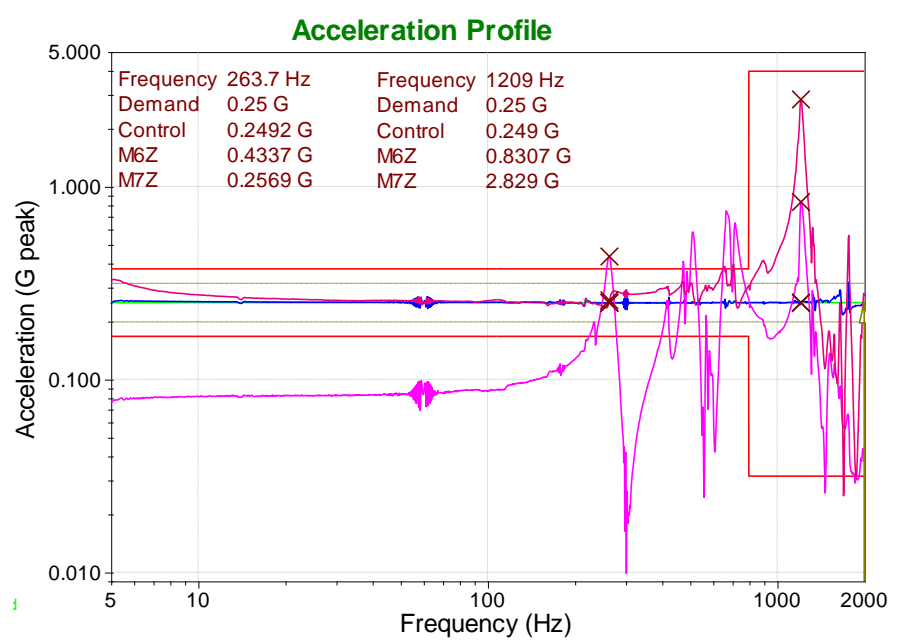

Figure 25. TELEDYNE PRE-QUALIFICATION TEST ZAXIS SINE SWEEP. 


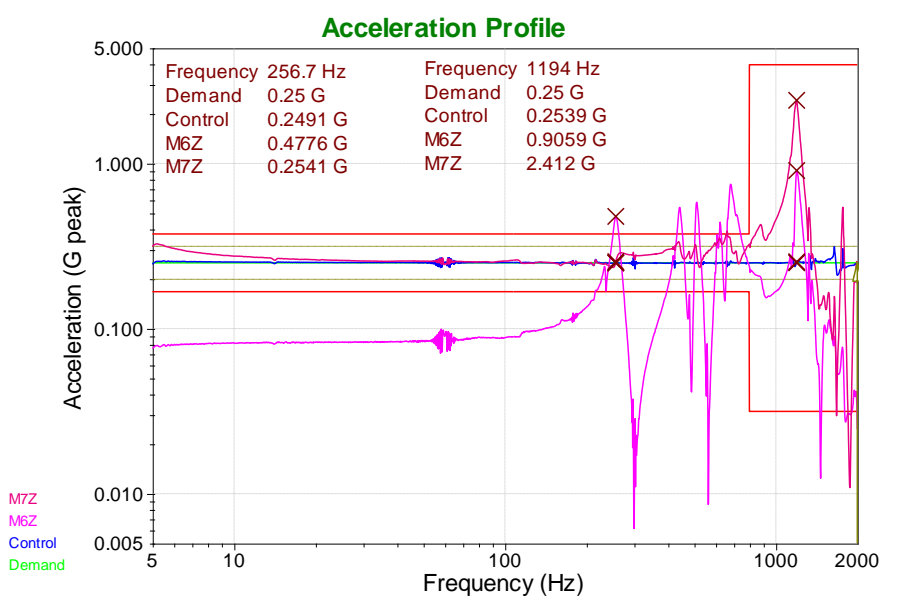

Figure 26. TELEDYNE POST-QUALIFICATION TEST ZAXIS SINE SWEEP.

\subsection{Infinity Pressure Decay Test Summary}

Figure 27 shows the measured pressure decay of the Infinity stack during the $\mathrm{Y}$-axis qualification testing. The stack was pressurized to $30 \pm 1$ psig with helium which is representative of the nominal stack operating pressure. The hydrogen, oxygen, and product water passages were all at a balanced pressure. The orange highlighted part of curve, beginning at 8 minutes in Figure 27 is when the qualification levels are reached. The measured leak rate test includes the fuel cell stack and all plumbing and flex hoses to an isolation valve downstream the supply pressure regulator as illustrated in Figure 28. The pressure decay rate prior to the $10 \mathrm{~g}_{\mathrm{rms}}$ load is 0.054 $\mathrm{psi} / \mathrm{minute}$. The pressure decay rate during the $10 \mathrm{~g}_{\mathrm{rms}}$ load is $0.044 \mathrm{psi} /$ minute. Note the temporary reduction in pressure decay rate during vibration testing at $10 \mathrm{~g}_{\mathrm{rms}}$. The likely cause of this is that the mechanical energy put into the fuel cell from the shaker table may have increased the temperature of the gas which would result in an increase in pressure and thus giving the appearance of a reduction in leak rate. After the vibration test the pressure decay rate returned to $0.044 \mathrm{psi} /$ minute.

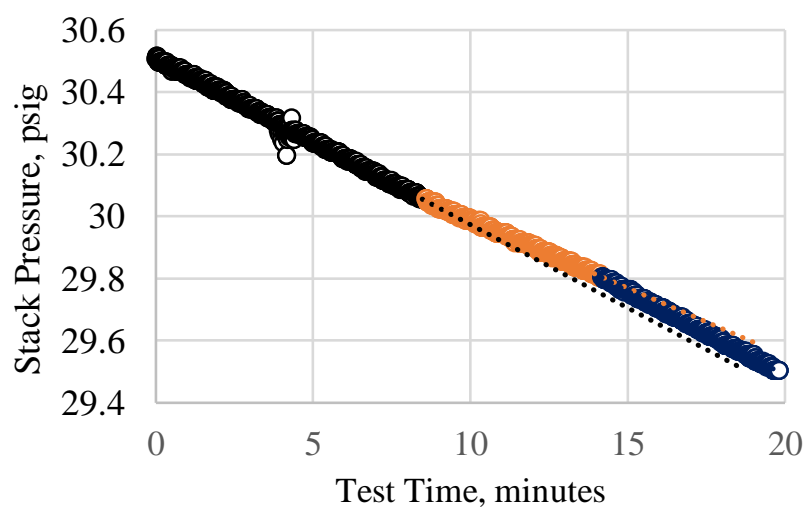

Figure 27. INFINITY STACK PRESSURE DECAY DURING Y-AXIS QUALIFICATION TEST.

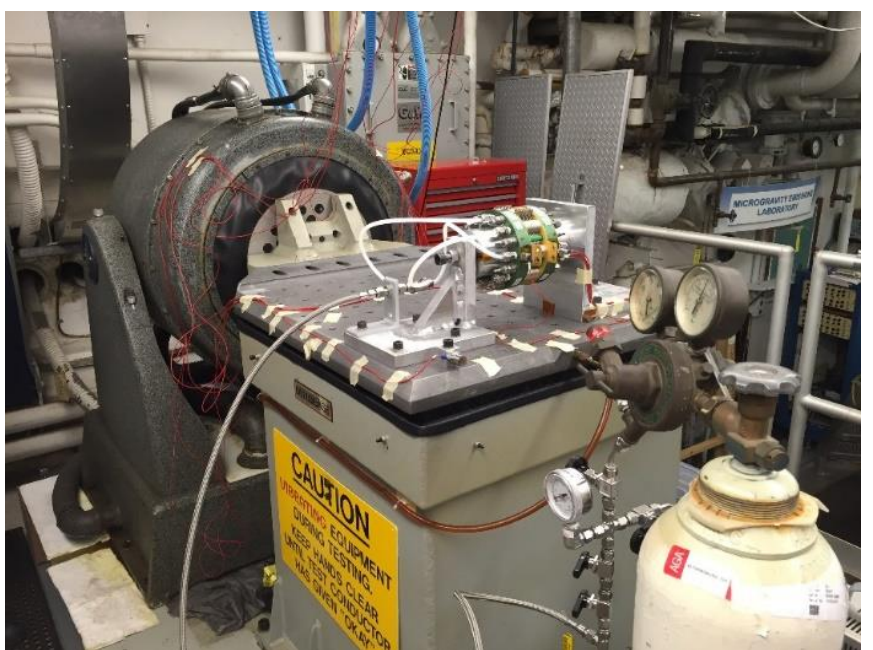

Figure 28. HELIUM SUPPLY CONFIGURATION DURING VIBRATION TESTING OF INFINITY STACK.

Figure 29 displays the Infinity stack pressure as a function of time during $\mathrm{Y}$-axis vibration testing. The leak rate is consistent over all the $\mathrm{Y}$-axis vibration tests at $0.050 \mathrm{psi} /$ minute. This leak rate is also consistent with the Baseline Stack Pressure Decay Rate. Similar results were observed for X-axis and Z-axis testing. The transfer of fluidic lines resulted in some variability between trials but the average leak rate was consistently within $\pm 10 \%$ of $0.050 \mathrm{psi} /$ minute for all tests, satisfying the success criteria identified by the project.

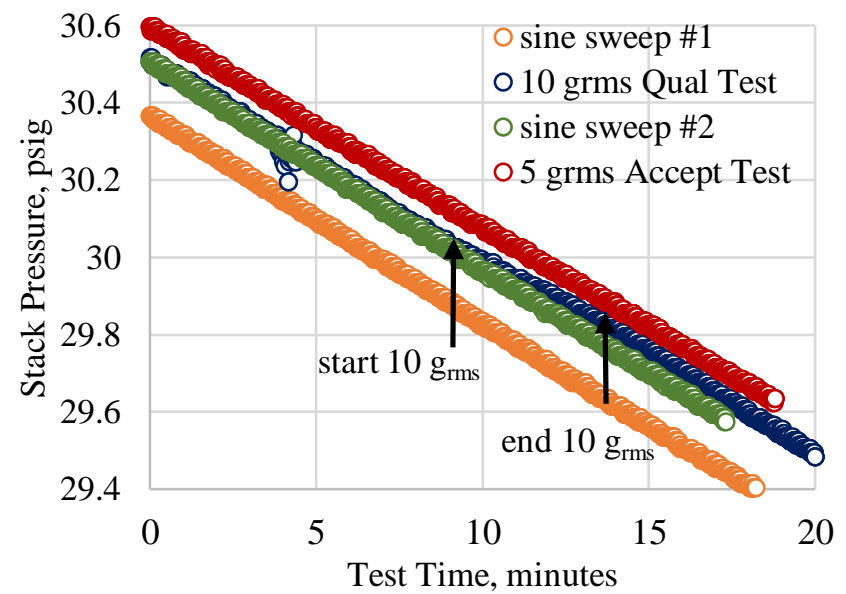

Figure 29. PRESSURE DECAY RATES DURING Y-AXIS VIBRATION TESTING FOR INFINITY FUEL CELL STACK.

\subsection{Teledyne Pressure Decay Test Summary}

Figure 30 shows the pressure decay of the Teledyne stack during the $\mathrm{Y}$-axis qualification level vibration testing. The stack was pressurized to $6 \pm 1$ psig with helium with the hydrogen, oxygen, and product water passages all at a balanced pressure. This pressure is representative of the stack nominal operating 
pressure. The pressure was monitored before, during, and after each vibration trial to establish a leak rate.

The leak rate test includes the fuel cell stack and all plumbing and flexible hoses from an isolation ball valve. No increase in pressure decay rate was observed over the baseline rate. In fact, there was a temporary reduction in pressure decay during vibration testing at $10.4 \mathrm{~g}_{\mathrm{rms}}$. The mechanism is likely the same as for the Infinity fuel cell stack. The temperature of the helium and any residual water may have increased from the vibrational energy load on the stack which would increase the pressure within the stack.

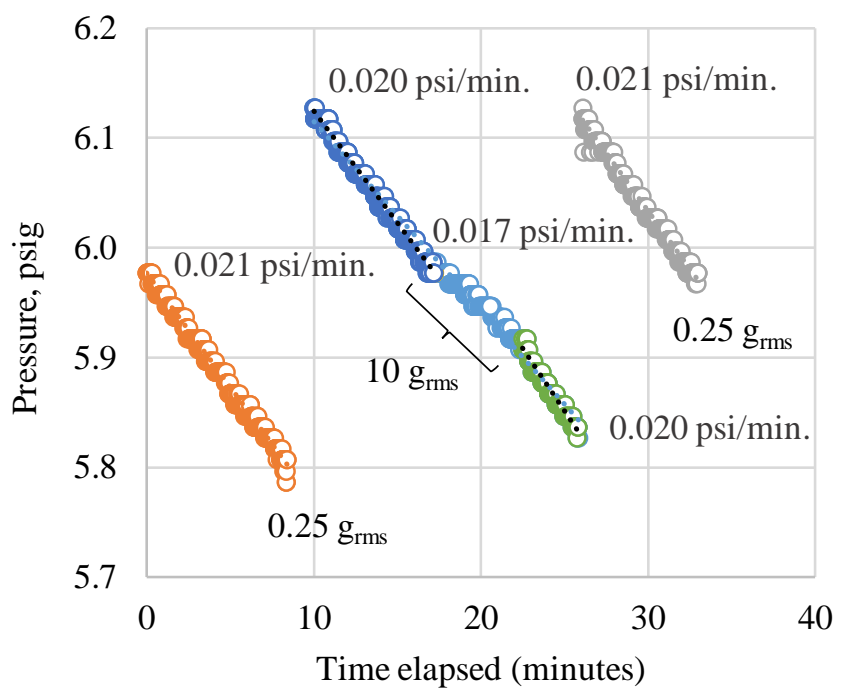

Figure 30. TELEDYNE STACK PRESSURE DECAY DURING Y-AXIS QUALIFICATION TEST.

The pressure decay rate is consistent over all the Y-axis vibration tests. The pressure decay rate is also consistent with the Baseline Stack Pressure Decay rate. Similar results were observed for $\mathrm{X}$-axis and Z-axis testing. The transfer of plumbing lines resulted in some variability between trials but the average leak rate was consistently within $\pm 10 \%$ of $0.021 \mathrm{psi} /$ minute for all tests.

\subsection{Infinity Electrochemical Performance Test Summary}

A NASA GRC's Common Test Bed (CTB) was utilized to perform operational testing of the fuel cell stack [4]. Once the fuel cell stack had reached full operational temperature, the NASA 2 Hour Load Profile test from Figure 1 was initiated. Fuel cell stack performance is measured by each cell's voltage for a given current density. The Infinity stack contained 12 cells at 50 $\mathrm{cm}^{2}$ active area per cell. Taking the average voltage of all the cells yields a representative cell voltage for a given current density. Figure 31 shows the average difference between the average cell potential before and after vibration testing. Fuel cell measurement variability is $\pm 8 \mathrm{mV}$ due to changes in pressure and temperature during testing. Although the difference in average cell potential slightly exceeds this value at high current densities, it can still be concluded that there is no meaningful change in performance resulting from exposure to vibration. As is illustrated in Figure 31, the percent deviation in average cell voltages for Baseline and Post-Vibration testing was below 1.5\% for all current densities, satisfying the $\pm 10 \%$ success criteria determined by the project.

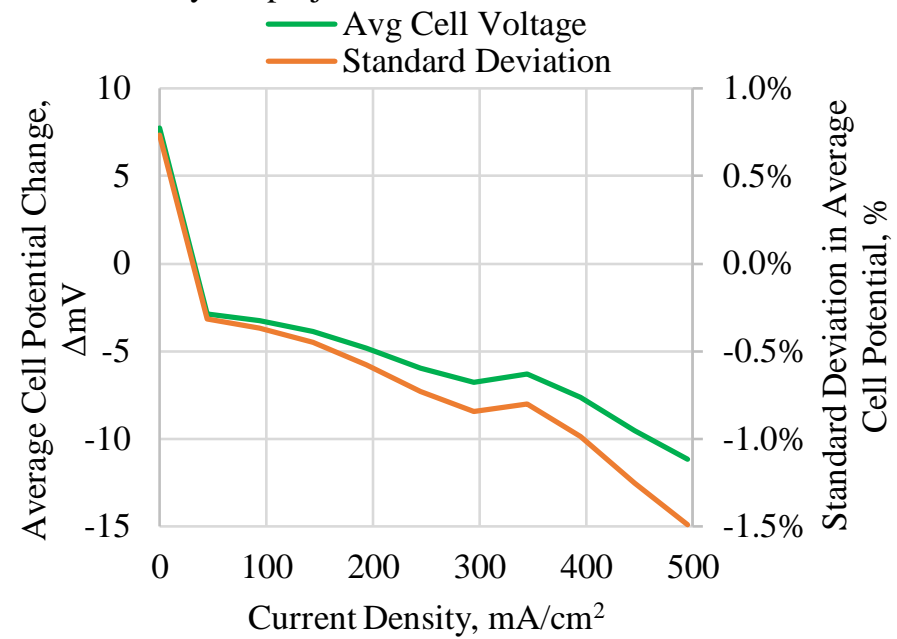

Figure 31. ELECTROCHEMICAL PERFORMANCE DIFFERENCE FROM BASELINE TESTING TO POSTVIBRATION TESTING FOR INFINITY STACK.

\subsection{Teledyne Electrochemical Performance Test Summary}

One of NASA GRC's CTB was modified to accommodate the flow-through nature of the Teledyne fuel cell and this modified CTB was utilized to perform operational testing of the Teledyne stack. Once the fuel cell stack had reached an operational temperature, the NASA 2 Hour Load Profile test from Figure 1 was initiated. The Teledyne stack contained 10 cells at $77 \mathrm{~cm}^{2}$ active area per cell. Figure 32 shows the average difference between the average cell potential before and after vibration testing. Similar to the Infinity results, the difference in average cell potential slightly exceeds the $8 \mathrm{mV}$ uncertainty value at high current densities. This is not a significant change in performance resulting from exposure to vibration. As is illustrated in Figure 32, the percent deviation in average cell voltages for Baseline and Post-Vibration testing for the Teledyne fuel cell stack was below $1.2 \%$ for all current densities, satisfying the $\pm 10 \%$ success criteria determined by the project. 


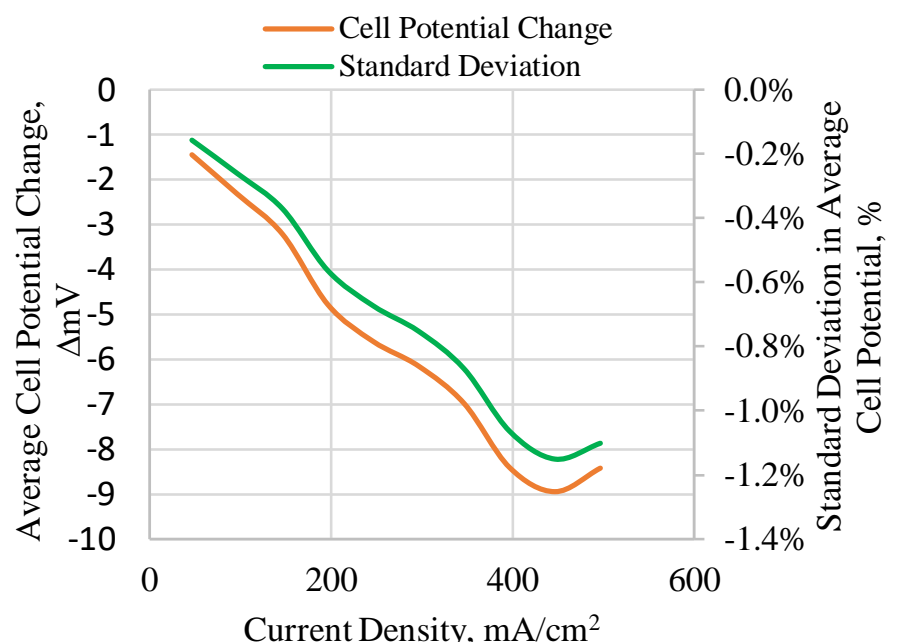

Figure 32. ELECTROCHEMICAL PERFORMANCE DIFFERENCE FROM BASELINE TESTING TO POSTVIBRATION TESTING FOR TELEDYNE STACK.

\section{CONCLUSION}

Qualification random vibration testing at $10.4 \mathrm{~g}_{\mathrm{rms}}$ for five minutes in each axis was successfully completed on air-independent fuel cell stacks from Infinity Fuel Cell and Hydrogen, Inc. and Teledyne Energy Systems, Inc. No structural anomalies were observed on either test unit for any of the axes of vibration during these qualification level tests. Performance results were within the required program specifications both before and after the vibration test at qualification levels with no significant change observed. Pressure decay rates for both fuel cell stacks had less than $10 \%$ variation in Baseline and Post-Vibration measurements, satisfying the success criteria for this metric. The deviation in average cell potential from Baseline testing to Post-Vibration testing was below $2 \%$ for both fuel cell stacks for all current densities tested. The fuel cell stacks successfully passed all test criteria for vibration testing at representative LVUS qualification levels.

\section{ACKNOWLEDGEMENTS}

Joseph Ursic, Trevor Jones, James Winkel, and Vicente Suarez - NASA GRC Structural Dynamics Laboratory.

William Smith - Infinity Fuel Cell and Hydrogen.

Robert Utz - Teledyne Energy Systems.

\section{REFERENCES}

[1] Jakupca, I., Bennett, W., Smith, P., and Burke, K. "Fuel Cell Research and Development for Earth and Space Applications." Department of Energy Annual Merit Review. June 2018.
[2] Polsgrove, T., Button, R., Linne, D. "Altair Lunar Lander Consumables Management." AIAA Space 2009 Conference and Exposition. September 2009.

[3] Hoberecht, M. and Jakupca, I. "Development Status of PEM Non-Flow-Through Fuel Cell System Technology for NASA Applications.” NASA TM 2011-217107.

[4] Manzo, Michelle. "NASA Glenn Research Center Electrochemistry Branch Overview." NASA Energy Storage Workshop. July 2010. 